\title{
DO FINANCIAL SECTOR STRUCTURE AND DEVELOPMENT MATTER FOR THE EFFECT OF BANK CAPITAL ON LENDING IN LARGE EU BANKS?
}

\section{Introduction}

The magnitude of the effect of changes in bank capital on the extension of bank credit has been one of the most important questions of the crisis, due to the role that banks play in the economy. In the European Union (EU) context, with bank-oriented financial systems, bank capital may be even more salient, as capital losses may result in reduced lending and therefore be a hindrance to real economy investment activity and thus economic growth. As implementation of more restrictive Basel III capital standards in the EU is accelerating, due to the formal acceptance of its rules into a directive $^{1}$ and a regulation ${ }^{2}$ in 2013 and due to relatively scant evidence on the role of bank capital in lending activity in the EU, it seems vital to answer the question what the impact of capital ratios on the EU banks' lending is.

As previous cross-country studies suggest that the procyclicality of bank capital regulation is alleviated by more stringent bank regulations and supervision, ${ }^{3}$ we ask whether additional country specific factors influence the size of the effect of the bank capital ratio on lending during contractions in the EU. We hypothesise that

\footnotetext{
* Uniwersytet Warszawski, Wydział Zarządzania.

** Uniwersytet Ekonomiczny w Krakowie, Wydział Zarządzania.

*** Uniwersytet Łódzki, Wydział Ekonomiczno-Socjologiczny oraz Narodowy Bank Polski.

1 See DIRECTIVE 2013/36/EU OF THE EUROPEAN PARLIAMENT AND OF THE COUNCIL of 26 June 2013 on access to the activity of credit institutions and the prudential supervision of credit institutions and investment firms, amending Directive 2002/87/EC and repealing Directives 2006/48/EC and 2006/49/EC (L 176).

2 REGULATION (EU) No 575/2013 OF THE EUROPEAN PARLIAMENT AND OF THE COUNCIL of 26 June 2013 on prudential requirements for credit institutions and investment firms and amending Regulation (EU) No. 648/2012 (L 176).

3 See M. Olszak, M. Pipień, I. Kowalska, S. Roszkowska, The effects of capital on bank lending of large EU Banks? - the role of procyclicality, income smoothing, regulations and supervision, "Faculty of Management Working Paper Series" 2014, Vol. 5.
} 
in countries with a financial sector structure that is more capital markets oriented and with a more developed financial sector the impact of capital ratio on loan supply in contractions is enhanced.

Previous papers concentrate ${ }^{4}$ on the effects of bank capital on lending, both in expansions and in recessions within a single country or in a limited sample of countries. They do not take account of the role of the cross country differences for the association between lending and capital ratios in contractions. Our study makes two contributions relative to the literature. First, we focus on the impact of financial sector structure on the effect of bank capital on loan growth in contractions. Second, we test the role of financial sector development in the association between loan growth and the capital ratio in contractions.

To test our hypotheses we apply a two-step GMM robust estimator (Arrelano and Bond, 1991, Blundell and Bond, 1998) for data spanning 1996-2011 on individual banks available in the Bankscope database.

The rest of the paper is organised as follows. Section 2 develops our hypotheses. We describe our sample and research design in Section 3. We discuss results in Section 4 . Section 5 concludes our work.

\section{Hypotheses}

Banks facing external financing frictions, such as the Myers and Majluf ${ }^{5}$ adverse-selection problem, cannot immediately restore equity capital declines, which may result in reduction of lending and thus have negative consequences for the economy. ${ }^{6}$ Some authors suggest that this reduction due to insufficient capital is stronger in recessionary than in expansionary periods. ${ }^{7}$ Our objective is to test if such an effect exists in the case of EU countries, especially those which have more market-oriented economies

4 To get access to a detailed literature review see M. Olszak, M. Pipień, I. Kowalska, S. Roszkowska, The Effects of capital on bank lending ..., op.cit.

5 S. Myers, N. Majluf, Corporate financing and investment decisions when firms have information that investors do not have, "Journal of Financial Economics" 1984, Vol. 13, pp. 187-221.

6 See e.g. M. Volk, P. Trefalt, Access to Credit as Growth Constraint, "Journal of Banking and Financial Economics" 2014, Vol. 1(1), pp. 29-29; and S.J. Van den Heuvel, Banking Conditions and the Effects of Monetary Policy: Evidence from U.S. States, Federal Reserve Board, Working Paper, 2011.

7 See: A. Beatty, S. Liao, Do delays in expected loss recognition affect banks' willingness to lend?, "Journal of Accounting and Economics" 2011, Vol. 52, pp. 1-20.; L. Gambacorta, D. Marqués-Ibáñez, The bank lending channel. Lessons from the crisis, Working Paper Series No. 1335/May 2011, European Central Bank; C. Borio, V.H. Zhu, Capital Regulation, Risk-Taking, and Monetary Policy: A Missing Link in the Transmission Mechanism?, "Journal of Financial Stability" 2012, Vol. 8, pp. 236-251. 
or which have better developed financial sector. The experience of the financial crisis in 2007 and 2008 showed that countries in which the financial sector plays an important role in the economy, are more prone to shocks stemming from financial markets in generally, and from the banking sector in particular. We ask whether such shocks may be caused by (probably insufficient) capital ratios which banks keep in such economies. To resolve this problem we put forward two hypotheses:

\section{H1: In countries which are more capital market-oriented the association between loan growth and the capital ratio in contractionary periods is strengthened. H2: The higher the development of financial sector, the more important the bank capital for loan extension.}

\section{Data and research methodology}

\subsection{Data}

We use pooled cross-section and time series data of individual banks' balance sheet items and profit and loss accounts from $27 \mathrm{EU}$ countries and country-specific macroeconomic indicators for these countries, over a period from 1996 to 2011. The balance sheet and profit and loss account data are taken from unconsolidated financials available in the Bankscope database, whereas the macroeconomic data were accessed from the EUROSTAT and the IMF web pages. We exclude from our sample outlier banks by eliminating the extreme bank-specific observations when a given variable adopts extreme values. Since most of these institutions are located in Ireland, the number of countries included in the final sample drops to 26. Based on this selection strategy, the number of banks included in our sample is 2523 (27359 observations and 26 countries).

To explore the relation between the sensitivity of loan growth to the capital ratio in contractions and the financial structure (FINSTR) we apply the aggregated indicator constructed by Beck and Levine ${ }^{8}$ which is the first principal component of two variables that measure the comparative activity and size of markets and banks. Each of the underlying variables is constructed in such a way that higher values indicate more market-based financial systems. The first variable equals the log of the ratio of

8 T. Beck, R. Levine, Industry growth and capital allocation: does having a market-or bank-based system matter?, "Journal of Financial Economics" 2002, Vol. 64, pp. 147-180. 
value traded (equal to the value of stock transactions as a share of national output) to bank credit (which equals the claims of the banking sector on the private sector as a share of GDP). The second variable equals the log of the ratio of market capitalisation to bank credit. Following Beck and Levine ${ }^{9}$ we define market capitalisation as the value of listed shares divided by GDP, and it is our measure of the size of stock markets relative to the economy. We use data for FINSTR averaged over the period of 1996-2010. We take all values, i.e. value traded, bank credit and market capitalisation from Beck et al. ${ }^{10}$ database updated for the current data. The computed principal component ranges from - 2.41 (in Slovenia) to 2.45 (in Sweden) and the higher its value, the more important the capital market in the economy.

We follow Beck and Levine ${ }^{11}$ and use Finance-Aggregate (FINDEV), which equals the first principal component of the two underlying measures of financial development. The first underlying measure is a measure of the overall activity of the financial intermediaries and markets. It equals the log of the product of private credit (the value of credits extended by financial intermediaries, both bank and nonbank intermediaries, to the private sector divided by GDP) and value traded (the value of total shares traded on the stock market exchange divided by GDP). The second underlying measure of financial development is a measure of the overall size of the financial sector and equals the log of the sum of private credit and market capitalisation. We aggregate data over the period of 1996-2010. We take all the values, i.e. value traded, bank credit and market capitalisation from Beck et al. ${ }^{12}$ database updated for the current data. The values of the first principal component range between -2.55 (in Romania) and 2.03 (in the United Kingdom), with higher values suggesting a more developed financial sector.

In our study we focus on the largest banks operating in each of the EU countries. We define the largest banks as $30 \%$ of banks with the largest assets in a given country. ${ }^{13}$

The empirical models that addressed the question of whether a bank capital induced credit crunch was hindering the recovery were developed in the early- and mid-1990 s in the US. We follow contemporary adoptions of those models, ${ }^{14}$ and our basic model reads as follows:

9 T. Beck, R. Levine, Industry growth and capital allocation..., op.cit.

10 T. Beck, B. Demirgüç-Kunt, R. Levine, Financial Institutions and Markets across Countries and over Time. Data and Analysis, Policy Research Working Paper 4943/2009, World Bank.

11 T. Beck, R. Levine, Industry growth and capital allocation ..., op.cit.

12 T. Beck, B. Demirgüç-Kunt, R. Levine, Financial Institutions and Markets across Countries ..., op.cit.

${ }^{13}$ For more details see M. Olszak, M. Pipień, I. Kowalska, S. Roszkowska, The effects of capital on bank lending..., op.cit.

14 See e.g.: J.M. Berrospide, R.M. Edge, The effects of bank capital on lending: What do we know? And what does it mean?, "International Journal of Central Banking" 2010, December issue, pp. 5-54; A. Beatty, 
Figure 1. Indices of financial sector structure (FINSTR) and financial sector development (FINDEV)

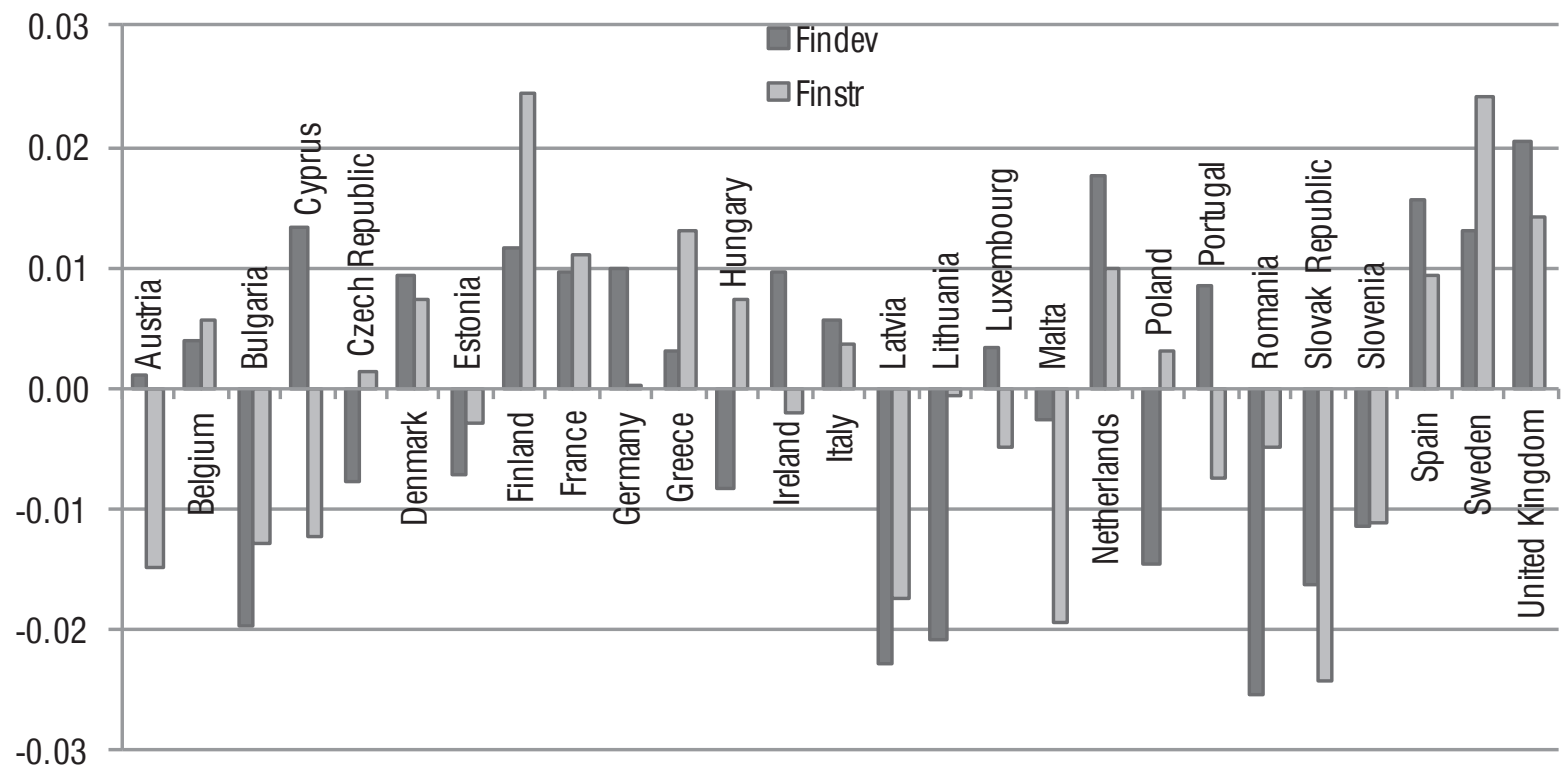

Source: Authors' calculations.

$$
\begin{aligned}
\Delta \text { Loan }_{i, t}= & \beta_{1}+\beta_{2} \text { Contraction } \beta_{2} \text { CAP }_{i, t}+\beta_{3}{\text { Contraction } * C A P_{i, t}+} \\
& +\beta_{4} \text { LIQCAP }_{i, t}+\beta_{5} \text { DEPBANKS } \\
i, t & +\beta_{6} \Delta \text { CAP }_{i, t}+\beta_{7} \text { QLP }_{i, t}+\beta_{8} \text { size }+ \\
& +\beta_{9} \Delta \text { UNEMPL }_{j, t}+\beta_{10} \sum_{j=1}^{27} \text { Country }_{j}+\beta_{11} \sum_{t=1996}^{2011} T_{t} \vartheta_{i, t}+\varepsilon_{t}
\end{aligned}
$$

where:

$i$ - the number of banks;

$j$ - the number of countries;

$t$ - the number of observations for the $i$-th bank;

$\Delta$ Loan - annual real loan growth rate;

Contraction - dummy equal to one in contractions and 0 otherwise;

$C A P$ - capital ratio, i.e. equity capital divided by total assets;

ContractionxCAP - interaction term between contraction and CAP;

LIQGAP - liquidity gap, calculated as (loans to nonfinancial sector minus deposits of nonfinancial sector minus interbank deposits)/loans to nonfinancial sector; this

S. Liao, Do delays in expected loss recognition affect banks' willingness to lend? ..., op cit; M. Carlson, $\mathrm{H}$. Shan, M. Warusawitharana, Capital ratios and bank lending: A matched bank approach, "Journal of Financial Intermediation" 2013, Vol. 22, pp. 663-687; J. Bridges, D. Gregory, M. Nielsen, S. Pezzini, A. Radia, M. Spaltro, The impact of capital requirements on bank lending, Working Paper 2014, No. 486, Bank of England; C. Labonne, G. Lame, Credit growth and bank capital requirements: binding or not?, Working Paper 2014. 
variable measures the extent to which bank loans are financed by unstable funding (i.e. securitisations, etc.);

$D E P B A N K S$ - deposits from banks divided by total assets;

$\triangle C A P$ - annual change in capital ratio;

$Q L P$ - quality of lending portfolio; it equals loan loss provisions divided by average loans;

size - logarithm of assets;

$\triangle U N E M P L$ - annual change in unemployment rate.

Annual change in unemployment rate is our measure of demand for loans. The unemployment rate is included because it not only reflects the business cycle but also longer term and structural imbalances in economies. We hypothesise that microprudential behaviour of banks is reflected by a positive correlation with unemployment. One can also expect banks operating in countries with lower unemployment to meet a higher credit demand as the income may be considered to be more stable. ${ }^{15}$

Elements $\sum_{j=11}^{27}$ Country $_{j}$ and $\beta_{11} \sum_{t=1996}^{2011} T_{t} \vartheta_{i, t}+\varepsilon_{t}$ are a set of country and time dummy variables, $\vartheta$ are unobservable bank specific effects that are not constant over time but vary across banks. Finally, $\varepsilon$ is a white-noise error term.

We predict a negative coefficient on Contraction, if loan supply declines during contractions for reasons other than capital and liquidity constraints. ${ }^{16}$

If external financing is not frictionless, and banks are concerned that they might violate regulatory capital requirements, then the coefficient on CAP is expected to be positive, i.e. banks with higher capital ratio will extend more loans.

To test the impact of financial sector structure and financial sector development, in particular during contraction periods, we include in equation (1) the indices which measure financial sector structure and development as well as interaction terms between each of those indices and ContractionxCAP. We run separate regression for each of these indices and interaction terms between them and ContractionxCAP.

To identify contractionary periods we refer to the dataset available in a study of Olszak et al., ${ }^{17}$ which was prepared following the approach of Lenart and Pipien. ${ }^{18}$

Our econometric model involves explanatory variables that may not be exogenous. This means that variables are correlated with error terms, both current and lagged.

15 J.A. Bikker, P.A.J. Metzemakers, Bank provisioning behaviour and procyclicality, "Journal of International Financial Markets, Institutions and Money" 2005, Vol. 15, pp. 141-157; G. Dell'Ariccia, D. Igan, L. Laeven, Credit booms and lending standards: Evidence from the subprime mortgage market, "Journal of Money, Credit and Banking" 2012, Vol. 44(23), pp. 367-384.

16 A. Beatty, S. Liao, op.cit.

17 M. Olszak et al., op.cit.

18 Ł. Lenart, M. Pipień, Almost periodically correlated time series in business fluctuations analysis, "Acta Physica Polonica” A 123(3)/2013, pp. 70-86. 
One may also observe heteroskedasticity effects and autocorrelation within individuals. Therefore, we apply an approach that involves instrumental variables. In order to limit the possible estimation bias, we consider the system of generalised method of moments (GMM). ${ }^{19}$ This method has a proven track record and seems to be the best approach to address three relevant econometric issues that are inherent to our analysis: (1) the presence of unobserved bank specific effects, which is eliminated by taking first differences of all variables; (2) the inclusion of lags of the dependent variable needed to capture the dynamic nature of loan growth, which brings about the autoregressive nature of the data regarding the behaviour of lending; and (3) the likely endogeneity of the explanatory variables, mentioned above.

We control for the potential endogeneity of CAP, LIQGAP, DEPBANKS, $\triangle$ CAP and QLP in the two step system GMM estimation procedure by the inclusion of up to four lags of explanatory variables as instruments. The UNEMPL, as well as country and time dummy variables are the only variables considered exogenous. As the consistency of the GMM estimator depends on the validity of the instruments, we consider two specification tests. The first is the test verifying the hypothesis of absence of second-order serial correlation in the first difference residuals $(\operatorname{AR}(2))$ and the absence of first-order serial correlation in the differentiated residuals (AR(1)). In particular, it is important that in the models applied there is no second-order serial correlation in error terms. The second test which we apply is the Hansen's J statistic for overidentifying restrictions, which tests the overall validity of instrument tests. When interpreting the p-values of Hansen's J statistics we follow Roodman's warning ${ }^{20}$ that the Hansen test should not be relied upon too faithfully, as it is prone to instrument proliferation.

\section{Empirical results}

Results using observations for the whole period of 1996-2011 are shown in Table 1. To provide an overview of specification, we first estimate equation (1) using a pooled, time series regression including all large banks in all EU countries for the whole period. The results give also some evidence in favour of capital crunch hypothesis

19 See R. Blundell, S. Bond, Initial conditions and moment restrictions in dynamic panel data model, "Journal of Econometrics" 1998, Vol. 87, pp. 115-143.

20 D. Roodman, Practitioners corner: A note on the theme of too many instruments, "Oxford Bulletin of Economics and Statistics" 2009, Vol. 71, pp. 135-156. 
for large banks, because the association between loan growth rate and capital ratio is positive and statistically significant.

The results reported in Table 1 show that loan growth is generally lower in countries with more stock market-oriented financial sector, as the regression coefficient on FINSTR is negative - but not statistically significant. On the other hand, the impact of financial development (FINDEV) on loan growth is stronger, around $-1,1$, but only marginally significant.

As for the role of financial structure in the effects of capital ratio on lending during contractions, we find that the relationship between lending and interaction term between FINSTR and ContractioxCAP is positive and statistically significant. Similarly, the association between loan growth and ContractioxCAPxFINDEV is positive. This gives empirical support to the two hypotheses put forward in our paper. Therefore, we conclude that both measures of the characteristics of financial sector seem to increase the procyclical effects of the bank capital ratio on loan growth.

With respect to other variables, we find that liquidity stemming from stable financing (measured with LIQGAP) plays some role in the case of large banks. Better access to retail interbank financing does not affect lending capacity of our sample of banks. Increases in capital ratios, as expected, lead to decreased loan growth in all types of banks. Relatively poor quality of loans, as measured by loan loss provisions over average loans (QLP), tends to be associated with slower loan growth rates. Size also matters for the lending capacity of banks. On average, banks with larger assets extend more new loans, as the regression coefficient of size is positive and statistically significant. Such a result supports the view that big banks should be less prone to adjusting their credit portfolio in the event of external shocks (such as monetary policy changes or crises). We also find that loan growth is higher when unemployment rate is higher. This supports the notion that in the case of large banks, supply factors are more important for loan growth than demand effects.

Table 1. Empirical results

\begin{tabular}{|l|c|c|c|c|c|c|c|}
\hline \multicolumn{1}{|c|}{ Variables: } & \multirow{2}{*}{$\begin{array}{c}\text { Expected } \\
\text { sign }\end{array}$} & \multicolumn{2}{c|}{ All big banks } & \multicolumn{2}{c|}{ Interaction } & \multicolumn{2}{c|}{ Interaction } \\
\cline { 5 - 8 } & & & $p$-val & & $p$-val & & $p$-val \\
\hline$\Delta$ Lloan (-1) & $+/-$ & -0.080 & $\mathbf{0 . 0 4}$ & -0.080 & $\mathbf{0 . 0 3}$ & -0.080 & $\mathbf{0 . 0 4}$ \\
\hline & & $(-2.10)$ & & $(-2.16)$ & & $(-2.02)$ & \\
\hline$\Delta$ loan (-2) & $+/-$ & -0.103 & 0.17 & -0.107 & 0.15 & -0.109 & 0.15 \\
\hline & & $(-1.38)$ & & $(-1.44)$ & & $(-1.45)$ & \\
\hline Contraction & $+/-$ & -1.443 & 0.12 & -0.169 & 0.86 & -1.832 & $\mathbf{0 . 0 4}$ \\
\hline & & $(-1.57)$ & & $(-0.17)$ & & $(-2.03)$ & \\
\hline CAP & + & 0.530 & $\mathbf{0 . 0 1}$ & 0.559 & $\mathbf{0 . 0 1}$ & 0.466 & $\mathbf{0 . 0 3}$ \\
\hline
\end{tabular}




\begin{tabular}{|c|c|c|c|c|c|c|c|}
\hline \multirow[t]{3}{*}{ Variables: } & \multirow{2}{*}{$\begin{array}{c}\text { Expected } \\
\text { sign }\end{array}$} & \multicolumn{2}{|c|}{ All big banks } & \multicolumn{2}{|c|}{ Interaction } & \multicolumn{2}{|c|}{ Interaction } \\
\hline & & & $p$-val & & $p$-val & & $p$-val \\
\hline & & (2.72) & & (2.69) & & $(2.17)$ & \\
\hline \multirow[t]{2}{*}{ ContractionxCAP } & + & 0.069 & 0.61 & -0.166 & 0.30 & -0.010 & 0.95 \\
\hline & & $(0.51)$ & & $(-1.03)$ & & $(-0.07)$ & \\
\hline \multirow[t]{2}{*}{ LIQGAP } & + & -0.007 & 0.23 & -0.008 & 0.21 & -0.007 & 0.26 \\
\hline & & $(-1.20)$ & & $(-1.25)$ & & $(-1.12)$ & \\
\hline \multirow[t]{2}{*}{ DEPBANKS } & - & -0.019 & 0.80 & -0.021 & 0.78 & -0.019 & 0.80 \\
\hline & & $(-0.25)$ & & $(-0.28)$ & & $(-0.26)$ & \\
\hline \multirow[t]{2}{*}{$\triangle \mathrm{CAP}$} & - & -1.477 & 0.05 & -1.429 & 0.05 & -1.435 & 0.05 \\
\hline & & $(-1.99)$ & & $(-1.95)$ & & $(-1.94)$ & \\
\hline \multirow[t]{2}{*}{ QLP } & - & -0.364 & 0.51 & -0.259 & 0.64 & -0.400 & 0.44 \\
\hline & & $(-0.66)$ & & $(-0.46)$ & & $(-0.78)$ & \\
\hline \multirow[t]{2}{*}{ size } & + & 0.828 & 0.00 & 0.807 & 0.00 & 0.802 & 0.00 \\
\hline & & (3.92) & & (3.39) & & $(3.90)$ & \\
\hline \multirow[t]{2}{*}{$\Delta$ UNEMPL } & $+1-$ & 2.167 & 0.00 & 2.032 & 0.00 & 2.117 & 0.00 \\
\hline & & $(5.23)$ & & $(5.02)$ & & $(5.16)$ & \\
\hline \multirow[t]{2}{*}{ intercept } & & -11.116 & 0.01 & -11.082 & 0.02 & -9.422 & 0.05 \\
\hline & & $(-2.51)$ & & $(-2.27)$ & & $(-1.97)$ & \\
\hline \multirow[t]{2}{*}{ FINSTR } & $+/-$ & & & -0.597 & 0.39 & & \\
\hline & & & & $(-0.86)$ & & & \\
\hline \multirow[t]{2}{*}{ ContractionxCAP x FINSTR } & + & & & 0.292 & 0.10 & & \\
\hline & & & & $(1.63)$ & & & \\
\hline \multirow[t]{2}{*}{ FINDEV } & $+/-$ & & & & & -1.101 & 0.13 \\
\hline & & & & & & $(-1.51)$ & \\
\hline \multirow[t]{2}{*}{ ContractionxCAP x FINDEV } & + & & & & & 0.200 & 0.11 \\
\hline & & & & & & $(1.59)$ & \\
\hline AR (1) & & -1.63 & 0.10 & -1.660 & 0.10 & -1.660 & 0.10 \\
\hline $\mathrm{AR}(2)$ & & -0.77 & 0.44 & -0.70 & 0.49 & -0.64 & 0.53 \\
\hline Hansen test $p$-val & & & 0.00 & & 0.00 & & 0.00 \\
\hline No. of lags (for levels) & & 4 & & 4 & & 4 & \\
\hline No. of banks & & 657 & & 657 & & 657 & \\
\hline No. of observations & & 6068 & & 6068 & & 6068 & \\
\hline
\end{tabular}

Source: Authors' calculations.

The model is given by equation (1). Results are obtained for banks included in the category of the biggest banks, i.e. banks which belong to the $30 \%$ banks with the largest assets. The symbols have the following meaning: $\Delta$ loan - annual loan growth rate; Contraction - dummy equal to one in contractions and 0 otherwise; CAP - capital ratio, i.e. equity capital to total assets; ContractionxCAP - interaction 
between contraction and capital ratio (CAP); $\triangle \mathrm{CAP}$ - annual change in capital ratio; DEPBANKS - deposits from banks to total assets; LIQGAP - loans less total customer deposits less deposits from banks divided by loans; size - logarithm of total assets; QLP - loan loss provisions divided by average loans; $\triangle$ UNEMPL - change in annual unemployment rate. FINSTR is financial sector structure index. FINDEV is the index measuring the financial sector development. Coefficients for the country and time dummies are not reported. The models have been estimated using the GMM estimator with robust standard errors. The p-val denotes significance levels. T-statistics are given in brackets. Data range: 1996-2011.

\section{Conclusions}

In this paper we investigate the extent to which country specific environment proxied with financial sector structure and development affect the relationship between loan growth rate and the capital ratio of largest EU banks during contractionary periods.

The results of our study show that the role of capital ratio for loan growth is stronger than previous literature has found for other countries, in particular for the U.S. In the full sample of large banks the role of capital ratio on loan growth in contractions is relatively weak. However, if we take into account the differences in financial sector structure and development between EU countries, we find that the effect of capital ratio on lending is positive and statistically significant. Therefore, our results suggest that capital ratios are an important determinant of lending in the large EU banks in those countries which have a financial sector with greater dominance of stock markets or with a better developed financial sector.

Our results support the view that economies with both better developed financial sector and more capital market-oriented financial sector are more prone to procyclical impact of capital standards, as the impact of capital ratio on lending is strengthened in those countries which exhibit greater financial sector development and greater reliance to stock market financing. 


\section{Acknowledgements}

We gratefully acknowledge the financial support provided by Polish National Scientific Centre (NCN), decision no. DEC-2012/05/D/HS4/01356. This paper's findings, interpretations, and conclusions are entirely those of the authors and do not necessarily represent the views of institutions with which the authors are affiliated.

\section{References}

Basel Committee on Banking Supervision (BCBS), Basel III: a global regulatory framework for more resilient banks and banking systems, Bank for International Settlements, 2011.

Beatty A., \& Liao S., Do delays in expected loss recognition affect banks' willingness to lend?, "Journal of Accounting and Economics" 2011, Vol. 51, pp. 1-20.

Beck T., Levine R., Industry growth and capital allocation: does having a market- or bank-based system matter?, "Journal of Financial Economics" 2002, Vol. 64, pp. 147-180.

Beck T., Bank competition and financial stability: Friends or foes?, Policy Research Working Paper Series 4656/2008, The World Bank.

Beck T., Demirgüç-Kunt B., Levine R., Financial institutions and markets across countries and over time. Data and analysis, Policy Research Working Paper 4943/2009, World Bank.

Berrospide J.M., Edge R.M., The effects of bank capital on lending: What do we know? And What does it mean?, "International Journal of Central Banking" 2010, December issue, pp. 5-54. http://www.ijcb.org/journal/ijcb10q4a2.pdf also available as working paper at: http://www.federalreserve.gov/pubs/feds/2010/201044/201044pap.pdf

Bikker J.A., Metzemakers P.A.J., Bank provisioning behaviour and procyclicality, "Journal of International Financial Markets, Institutions and Money" 2005, Vol. 15, pp. 141-157.

Blundell R., Bond S., Initial conditions and moment restrictions in dynamic panel data model, "Journal of Econometrics" 1998, Vol. 87, pp. 115-143.

Borio C., Zhu V.H., Capital regulation, risk-taking, and monetary policy: A missing link in the transmission mechanism?, "Journal of Financial Stability" 2012, Vol. 8, pp. 236-251.

Bridges J., Gregory D., Nielsen M., Pezzini S., Radia A., Spaltro M., The impact of capital requirements on bank lending, Working Paper No. 486/2014, Bank of England.

Carlson M., Shan H. Warusawitharana M., Capital ratios and bank lending: A matched bank approach, "Journal of Financial Intermediation" 2013, Vol. 22, pp. 663-687.

Dell'Ariccia, G., Igan D., \& Laeven L., Credit booms and lending standards: Evidence from the subprime mortgage market, "Journal of Money, Credit and Banking" 2012 Vol. 44, No. 23, pp. 367-384. 
DIRECTIVE 2013/36/EU OF THE EUROPEAN PARLIAMENT AND OF THE COUNCIL of 26 June 2013 on access to the activity of credit institutions and the prudential supervision of credit institutions and investment firms, amending Directive 2002/87/EC and repealing Directives 2006/48/EC and 2006/49/EC (L 176).

Gambacorta L., Marqués-Ibáñez D., The bank lending channel. Lessons from the crisis, Working Paper Series No 1335/May 2011, European Central Bank.

Labonne C., Lame G., Credit growth and bank capital requirements: binding or not?, Working Paper 2014 https://www.banque-france.fr/fileadmin/user_upload/banque_ de_france/Economie_et_Statistiques/Credit-growth-and-bank-capital-requirementsbinding-or-not.pdf

Lenart Ł., Pipień M., Almost periodically correlated time series in business fluctuations analysis, "Acta Physica Polonica" A 123(3)/2013, pp. 70-86.

Myers S., Majluf N., Corporate financing and investment decisions when firms have information that investors do not have, "Journal of Financial Economics" 1984, Vol. 13, pp. 187-221.

Olszak M., Pipień M., Kowalska I., Roszkowska S., The effects of capital on bank lending of large EU Banks? The role of procyclicality, income smoothing, regulations and supervision, "Faculty of Management Working Paper Series" 2014, Vol. 5, retrieved from: papers.ssrn.com $/ \mathrm{sol}^{3} /$ papers.cfm?abstract_id=2543675.

REGULATION (EU) No 575/2013 OF THE EUROPEAN PARLIAMENT AND OF THE COUNCIL of 26 June 2013 on prudential requirements for credit institutions and investment firms and amending Regulation (EU) No 648/2012 (L 176).

Roodman D., Practitioners Corner: A note on the theme of too many instruments, "Oxford Bulletin of Economics and Statistics" 2009, Vol. 71, pp. 135-156.

Van den Heuvel S.J., Banking conditions and the effects of monetary policy: evidence from U.S. States, Federal Reserve Board, Working Paper, 2011.

Volk, M., \& Trefalt, P. Access to Credit as Growth Constraint, "Journal of Banking and Financial Economics" 2014, Vol. 1, No. 1, pp. 29-39.

\section{Do Financial Sector Structure and Development Matter for the Effect of Bank Capital on Lending in Large EU Banks?}

The paper aims at finding out what is the impact of bank capital ratios on loan supply in the EU and what factors explain the potential diversity of this impact. Applying the Blundell and Bond (1998) two step GMM estimator, we find that in the full sample of large banks the role of capital ratio on loan growth in contractions is relatively weak. However, if we take into account the differences in financial 
sector structure and development between EU countries, we find that the effect of capital ratio on lending is positive and statistically significant. Therefore, our results suggest that capital ratios are an important determinant of lending in the large EU banks in those countries where financial sector is more dominated by stock markets of is better developed. Thus, our results provide support for the view that more financially developed economies are prone to greater procyclical impact of capital ratios on lending of banks.

Keywords: loan supply, capital ratio, financial sector structure, financial sector development, procyclicality

\section{Est-ce que la structure du secteur financier et son développement sont- ils importants pour l'effet de capital de la banque sur les prêts dans les grandes banques de l'UE?}

Le document vise à découvrir quel est l'impact des ratios de fonds propres des banques sur l'offre de crédit dans l'UE et quels facteurs expliquent la diversité potentielle de cet impact. Grâce à l'application de l'estimateur GMM de Blundell et Bond (1998), nous constatons que, dans l'échantillon de grandes banques le rôle du ratio de capital sur la croissance des prêts dans contractions est relativement faible. Cependant, si nous prenons en compte les différences dans la structure du secteur financier et dans le développement entre les pays de l'UE, nous constatons que l'effet de ratio de capital sur les prêts est positif et statistiquement significatif. Par conséquent, nos résultats suggèrent que les ratios de fonds propres sont un déterminant important de prêter dans les grandes banques de l'UE dans les pays où le secteur financier est plus dominé par les marchés boursiers et est mieux développé. Ainsi, nous observons que les économies plus développées financièrement sont sujettes à un plus grand impact procyclique des ratios de fonds propres sur les prêts des banques.

Mots-clés: l'approvisionnement de prêt, le ratio de capital, la structure du secteur financier, le développement du secteur financier, la procyclicité 


\section{Имеет ли значение уровень развития и структура финансового сектора для влияния показателей капитала на кредитование в крупных банках EC?}

Цель статьи определить влияние показателей капитала банков на предложение кредита в ЕС и указать какие факторы объясняют потенциальное разнообразие этого воздействия. Применяя процедуру Бланделла-Бонда (1998), находим, что в полной выборке крупных банков влияние показателей капитала на рост кредитования во время экономического спада является относительно слабым. Тем не менее, если принять во внимание различия в структуре и развитии финансового сектора между странами ЕС, видно, что влияние показателей капитала на кредитование является положительным и статистически значимым. Таким образом, результаты показывают, что коэффициенты достаточности капитала являются важным фактором, определяющим предложение кредита, в отношении крупных банков ЕС в тех странах, где финансовый сектор хорошо развит. Полученные результаты подтверждают, что страны с лучше развитыми финансовыми рынками больше подвергаются проциклическому влиянию показателей капитала на предложение кредита.

Ключевые слова: предложение кредита, коэффициент капитала, структура финансового сектора, уровень развития финансового сектора, процикличность 